\title{
Spatial genetic structure of Stryphnodendron adstringens (MART.) COVILLE (Leguminosae- Mimosoideae) using SSR markers
}

\author{
Léo Zimback ${ }^{1 *}$, Edson Mori ${ }^{2}$, Eliete Branco ${ }^{3}$, Adriano Lima², Eliseu Baena ${ }^{1}$ \\ From IUFRO Tree Biotechnology Conference 2011: From Genomes to Integration and Delivery \\ Arraial d'Ajuda, Bahia, Brazil. 26 June - 2 July 2011
}

\section{Background}

The forest fragments of Stryphnodrendron adstringens have disappeared because of the high rate of Brazilian Savannah deforestation for commercial purposes, such as eucalypt, citrus, soy bean, and sugar cane crops that have been intensely cultivated on those areas [1]. Economically, $S$. adstringens is important for manufacture industries of paints and tanneries, but also is utilized for therapy against ulcer, scurvy, and for antiseptic and healing purposes [2]. Considering the forestry sector, the species is potential for building uses because of their wood have high density and durability [3]. Aiming for germplasm preservation and for breeding programs we studied the spatial genetic structure of $S$. adstringens based on SSR markers.

\section{Methods}

Juvenile leaves of 38 individuals of $S$. adstringens were collected in natural population, of approximately 200 individuals, in Botucatu State Forest belonging to Forestry Institute, São Paulo State, Brazil. The population is located from $22^{\circ} 55^{\prime} 55^{\prime \prime} \mathrm{S}$ to $22^{\circ} 56^{\prime} 39^{\prime \prime} \mathrm{S}$ latitude and from $48^{\circ} 27^{\prime} 19^{\prime \prime} \mathrm{W}$ to $48^{\circ} 27^{\prime} 33^{\prime \prime} \mathrm{W}$ longitude, through $860 \mathrm{~m}$ altitude, totalizing 33 hectares of savannah. The lab procedure protocol based on Ferreira and Grattapaglia [4], and adapted to S. adstringens, for DNA extraction was used. We assessed the transferability of 98 primer pairs developed for different tree species of several families and genera. The amplification was performed at $92^{\circ} \mathrm{C}$ for 2 minutes by initial denaturation, 45 cycles of 1 minute at $92^{\circ} \mathrm{C}, 1$ minute at annealing temperature, and $1 \mathrm{~min}$ at $72^{\circ} \mathrm{C}$, and ending to 10

\footnotetext{
* Correspondence: Izimback@terra.com.br

'Instituto Florestal, Avaré, SP, 18701-180, Brazil

Full list of author information is available at the end of the article
}

minutes at $72^{\circ} \mathrm{C}$. The analysis of spatial autocorrelation of sampled population, with local coordinates, and variable alleles of individuals was estimated. The "Spatial Genetic Software (SGS) version 1.0 program for distance classes per each allele, and considering 1000 bootstraps to get the Moran's I Index [5] were used. The expression was:

$$
I=\left(\frac{n}{W}\right) \cdot\left[\frac{\sum_{i} \sum_{j}\left(p_{i}-p\right)\left(p_{j}-p\right) W_{i j}}{\sum_{i}\left(p_{i}-p\right)^{2}}\right]
$$

where:

$\mathrm{I}=$ Moran's I index, which can take values between -1.0 (negative autocorrelation) and +1.0 (positive autocorrelation);

$\mathrm{n}=$ number of individuals;

$\mathrm{pi}$ and $\mathrm{p} \mathbf{j}=$ allele frequency for $\mathrm{i}$ and $\mathbf{j}$ individuals;

$\mathrm{p}=$ average of $\mathrm{p}$;

$\mathrm{Wij}=$ element of symmetric matrix square and $\mathrm{W}$ were nxn dimensions, which is given the value 1 for individual neighbors and 0 otherwise;

$\mathrm{W}=$ matrix that expresses the spatial correlation between individuals and the sum over $i$ and $j$ is the value iqual $\mathrm{W}$.

\section{Results and discussion}

Forty eight out of 98 pairs were amplified showing 23 polymorphic primers, but only 10 of them were conserved, and presenting no null alleles: EMBRA 03, EMBRA 06 (Eucalyptus grandis), EMBRA 72, EMBRA 210 (Eugenia dysenterica) Empas 02 (Prunus avium) LMCH 12, LMCH 14 (Annona cherimoya), SCU 056, SCU 062 (Melaleuca alternifolia), and SP 06 
Table 1 Correlogram using Moran's Index (D) with confidence interval $(\mathrm{CI})$, probability of exclusion $(\mathrm{P})$, number of comparisons (CN), and value indicating absence of spatial autocorrelation $D=-\mathbf{0 . 0 2 7 0}$ for Stryphnodendron adstringens.

\begin{tabular}{|c|c|c|c|c|c|c|}
\hline $\begin{array}{l}\text { Distance } \\
\text { (m) }\end{array}$ & $\mathrm{D}(-\mathrm{Cl})$ & D(obs.) & $\mathrm{D}(+\mathrm{Cl})$ & $\begin{array}{c}P(D)< \\
(-C l)\end{array}$ & $\begin{array}{c}\mathrm{P}(\mathrm{D})>(+ \\
\mathrm{Cl})\end{array}$ & $\overline{\mathrm{CN}}$ \\
\hline $0-33$ & -0.080841 & 0.043351 & 0.034583 & 0.015 & 0.985 & $\underline{40}$ \\
\hline $33-66$ & -0.078096 & -0.005722 & 0.023789 & 0.190 & 0810 & 45 \\
\hline $66-99$ & -0.079640 & -0.010610 & 0.031820 & 0.291 & 0.709 & 41 \\
\hline 99-132 & -0.081936 & -0.096614 & 0.032199 & $\underline{0.995}$ & $\underline{0.005}$ & $\underline{35}$ \\
\hline $132-165$ & -0.079713 & -0.015566 & 0.027000 & 0.355 & 0.645 & 38 \\
\hline 165-198 & -0.090142 & 0.025456 & 0.033938 & 0.046 & 0.954 & 37 \\
\hline 198-231 & -0.064909 & -0.059062 & 0.007197 & 0.954 & 0.046 & 75 \\
\hline $231-264$ & -0.086119 & -0.063560 & 0.031723 & 0.867 & 0.133 & 25 \\
\hline 264-297 & -0.114183 & -0.054740 & 0.074730 & 0.715 & 0.285 & 7 \\
\hline 297-330 & -0.103925 & -0.058399 & 0.052559 & 0.800 & 0.200 & 10 \\
\hline
\end{tabular}

(Schizolobium parahyba). O LMCH 12 locus was eliminated to present low accuracy. Table 1 shows the correlogram of S. adstringens indicating that the distances, among individuals of Botucatu State Forest, from 0 to 33 and from 99 to 132 meters have presented spatial structure. According to Sebbenn [6]is common in tropical species, similarities until 100 meters; therefore to collect high variability of $S$. adstringens it is important obeyed distance up to 132 meters.

\section{Conclusions}

Significant results were observed for the class distances from 0 to 33 meters and 99 to 132 meters, showing there is spatial autocorrelation for $S$. adstringens.

\section{Acknowledgements}

The authors thank FAPESP to provide financial funds to develop the study, CNPq and CAPES for scholarships.

\section{Author details}

${ }^{1}$ Instituto Florestal, Avaré, SP, 18701-180, Brazil. ${ }^{2}$ Unesp, Botucatu, SP, 18610 307, Brazil. ' University Sagrado Coração, Bauru, SP, 17011-160, Brazil.

Published: 13 September 2011

\section{References}

1. Machado SR: Pesquisa aponta degradação do Cerrado. Jornal Diário do Serra 2006, A3.

2. Jacobson, Garcia J, Santos SC, Duarte JB, Farias JG, Kliemann HJ: Influência de fatores edáficos na produção de fenóis totais e taninos de duas espécies de barbatimão (Stryphnodendron sp.). Pesquisa Agropecuária Tropical 2005, 35:163-169.

3. Almeida SP, Sano SM: Cerrado: espécies vegetais úteis. Brasília: EMPRAPA Cerrado 1998, 347-351.

4. Ferreira ME, Grattapaglia D: Introdução ao Uso de Marcadores Moleculares em Análise Genética. 1998, 121.

5. Sokal RR, Oden NL: Spatial autocorrelation in biology. 2. Some biological implications and four applications of evolutionary and ecological interest. Biological Journal of the Linnaean Society 1978, 10:229-249.

6. Sebbenn AM: Sistemas de reprodução em espécies tropicais e suas implicações para a seleção de árvores matrizes para reflorestamentos ambientais. In Pomar de sementes de espécies florestais nativas Higa AR, Silva LD 2006, 93-138.

doi:10.1186/1753-6561-5-S7-P21

Cite this article as: Zimback et al:: Spatial genetic structure of Stryphnodendron adstringens (MART.) COVILLE (LeguminosaeMimosoideae) using SSR markers. BMC Proceedings 2011 5(Suppl 7):P21.

\section{Submit your next manuscript to BioMed Central and take full advantage of:}

- Convenient online submission

- Thorough peer review

- No space constraints or color figure charges

- Immediate publication on acceptance

- Inclusion in PubMed, CAS, Scopus and Google Scholar

- Research which is freely available for redistribution 